\title{
TRADITIONAL CHILDCARE AND TREATMENT OF CHILDREN'S DISEASES AMONG THE BESERMIAN
}

\section{Yelena Popova}

\begin{abstract}
The article is based on fieldwork conducted in 1986-2000 among the Besermian (a small ethnic group in North-East Udmurtia, the districts of Iukamen, Iar, Balezino and Glazov, and the Cheptsa watershed).

The article overviews the beliefs, customs and healing practices applying to labour, care of the mother and the newborn. Also, Besermian midwives and verbal healers and their practices are reviewed. The Besermian retained traditional medicine longer than the neighbouring groups, especially as regards child healing methods. Diseases and healing practices of complex mythological background are slowly forgotten, knowledge and practices relayed within a family have survived better. Children's diseases and prophylactics are treated similarly to that of adults. Receiving health from an adult and the ritual of "new" birth played an important role.

Keywords: labour, folk medicine, children's diseases, mythological diseases, midwife, healer, Besermian.
\end{abstract}

The Besermian believed that the good fate and happiness of a newborn child was secured by a strict following of traditions and childcare in the first postnatal years. Many treatment methods are based on the understanding that a newborn baby is much more susceptible to the influence of various supernatural forces and spirits of illnesses, and the child's physical development and hygiene was attentively observed. Folk paediatrics, which was concerned with childcare and treatment, as well as prevention of children's diseases, may be viewed as an individual area of folklore. Knowledge about children's diseases, the peculiarities of infant development and the child's role in the world constitute a homogeneous symbiosis of rational methods and mythological-religious conceptualisations. This explains why the traditional treatment and curing methods of children's diseases are still considered an important part of family traditions.

The article was written in 1986-2000 on the basis of materials from fieldwork among the Besermian. The Besermian (or Beserman) 
people are a small ethnic group living in Iukamen, Iar, Balezino and Glazov Districts in the watershed of the Cheptsa River (a tributary to the Vyatka). The bulk of the informants were senior women, who generally tend to be more familiar with traditions about giving birth, treatment and childcare. The choice of informants was also determined by the fact that there were no prior descriptions of traditions; therefore, the characteristics of modern traditions had to be observed by means of describing the traditional forms of lore. The few existing ethnographic records unfortunately include no reference to raising children and childcare. Accounts about hygienic practices, spirits of illnesses and sacrifice were included in a single manuscript - one submitted to the Russian Geographical Society by K.A. Satrapinski (1854), a priest of the Ukan village; parts of the manuscript have been republished by N. Nikolski (1919: 77-78).

Childhood was divided in periods and childcare was determined according to a child's age. A newborn child was called 'a green child', 'an infant', 'suckling', 'a child holding head'. A child, who was at the crawling stage was called 'a human on all fours', while a child who took its first steps was referred to as someone who "finds its feet". Toddlers between the age of one and a half years and three years were called 'middlings', 'half-humans', 'small children'. The Besermian terminology connected with life cycle and the age stratification of a child is very similar to the Udmurt terms (Pervukhin 1890: 3; Nikitina 1996: 41). It must be noted, though, that the periodisation and categorisation of stages is highly individual: even members of the same family interpreted these differently. Age has probably always been categorised very generally and it has depended on the development of an individual child.

Sanitary conditions and hygiene used to be strictly observed and the newborn's health was carefully protected in early infanthood. During this time the child was considered weak and it was believed that the danger persisted until the child learned to walk. The main goals of treatment and child-raising were therefore the safe-keeping of the child's life and health, and developing its physical and motor skills. It was believed that the path to future health began at birth and in infancy, which formed the basis for the grown person's health. 
It was believed that all this may have been secured by observing the rituals and behavioural norms that accompany the most important development stages of a child.

A child is not completely physically formed by the time it is born, and its arrival in this world does not mean that labour is over. Owing to this reason, the child had to be "completed". In the first weeks and months, attempts to achieve the child's correct physical shape were made. This applied particularly to premature babies. A prematurely born baby was wrapped in sheepskin, held in a fur coat's sleeve, or warmed on the oven until it turned nine months old, for the child "to become ripe". The child was "baked" by swaying it on the baker's shovel (author's fieldwork materials, henceforth AFM 1991: N. K. Nevostrueva (born in 1919), Zhuvam village). For a child to grow tall, it was tightly wrapped up, massaged in the sauna and its hands and legs were slightly stretched. The proper shape of a child's head was round and smooth, which is why the baby's head was rectified and shaped - the child was taken to the sauna, its head was soaped in and lightly pressed from all sides. It was believed that taking a child to sauna made it grow faster and it would be physically healthy. This is why a baby was taken to the sauna several times during its first month (пинял муньчо - 'sauna for child', or 'child's sauna').

In the sauna, the ritual removing of child's "bristles" was performed it was believed that there are stiff "bristles" under the baby's skin in its shoulders, back, hands and legs. These "bristles" were called 'dog hair' - кочерга оr кочурга. The latter name appears to derive from a Russian loan word: the Russians traditionally call the children's "bristles" корчужка, or кочеружка. The Besermian believed that the bristles disturb the baby, it sleeps restlessly and does not lay on its back. The bristles were removed by the following method - breast milk was poured on the baby's back and in light strokes rubbed in the skin. Sometimes bread crumbs, bread dough or leaven was used instead of milk. The procedure was repeated until the "bristles" were gone.

There were certain rules that had to be observed in the sauna, and the rules were particularly strict when a baby was involved. It was not allowed to praise the child, play with it, call it by the name, or leave the child alone in the sauna, because otherwise the treatment 
and bathing was in vain. On the other hand, these rules were associated with fear that the child might fall ill, or that Shaitan, or Муньчо кузё 'master of the sauna' will replace it. The set of rules and fear of exchange indicate that the sauna was perceived as a border between the natural and the supernatural world, which is relatively common among other traditional cultures (Shabaev \& Shabaeva 1995: 52). Most children's diseases were treated in sauna. If a child cried a lot and slept restlessly, the best measure for curing it was "washing off" or "steaming out" the disease. The curative properties of the sauna were intensified with spells: a midwife or female healer was called to bathe the child. Sometimes the baby was bathed by old women or widows; this may be associated with their ritual purity. This speculation is further encouraged by the fact that a menstruating woman was not allowed to enter the sauna when a child was treated there. If a menstruating woman came to the sauna during a baby's regular bathing, she was not allowed to step higher than the baby. It was believed that if these rules were disobeyed, the child could fall ill, grow weak or whiny (AFM 1993: N. K. Nevostruev (b. in 1919), Zhuvam village, Iukamen District). After the bathing, especially after treatment in the sauna, it was not advised to praise the child or let it seen by strangers. It was believed that this would render the treatment useless and the child may be easily bewitched.

Traditional cleansing substances were used for caring for the child. Reddened spots and skin folds were carefully dried and the skin patted with self-made baby powder. The powder consisted of ground dry wood, roasted meal, burned and ground coquina, pollen of coniferous trees, dry ashes. Irritated skin was covered not with cotton wool, but flax fibres scraped with knife from clothes. Red and irritated spots were smeared with plant oil and fat. Good hygiene and keeping the child clean was considered vital in the prevention of diseases and maintaining health.

In the first few months after it was born, the newborn lied in the cradle кекj - a box of 30-40 cm in height, sewn from bast, with a strengthened bottom lined with string or bast and wooden boards. Some cradles had a wooden structure, lined with cloth. The cradle was tied to a long bending pole, and the other end was attached to a ring pinned in the ceiling. In order to protect the child from light, insects, and the evil eye, the cradle was covered with a linen or 


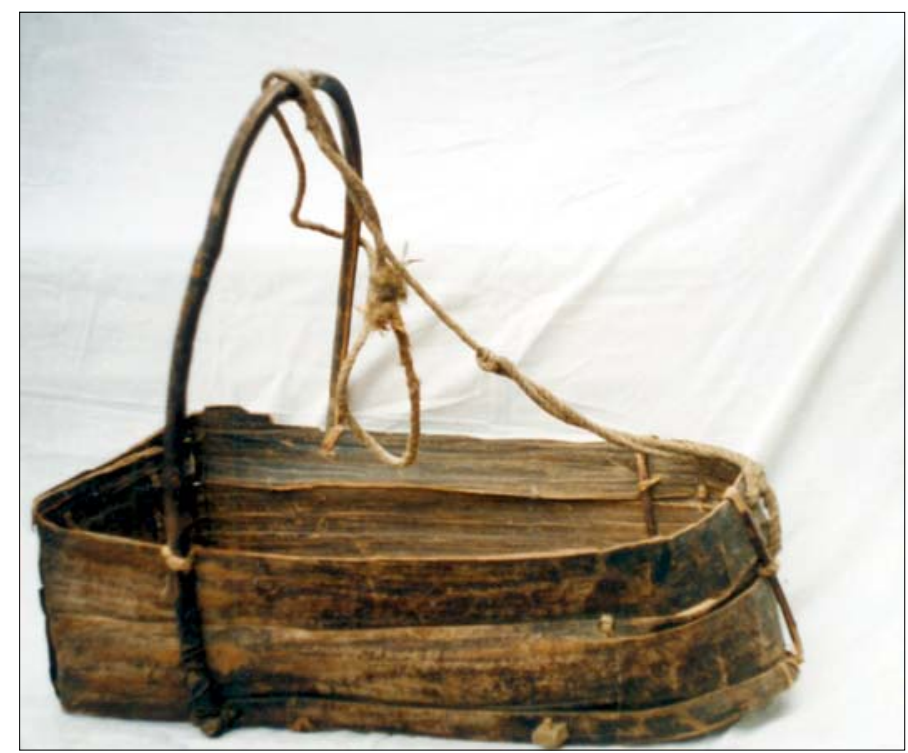

Figure 1. Bast cradle. Collection of the Glazov Institute of Pedagogy. Photo by the author.

cotton spread. If a stranger entered the room, especially someone from far away, the cradle was instantly covered. The cradle was rhythmically rocked by hand, or by means of a rope tied to the bottom of the cradle. It was not allowed to rock an empty cradle in fear that the child will lose its sleep. Wishes, reflections about one's fate and life, improvised texts were lulled. The improvisational lulling at the cradle touched topics like a hope that the child will fall asleep, be obedient, and love its parents. The humming followed the rhythm of rocking: "O-o-o! E-e-e!"

The bedclothes of an infant included a pillow йjpyлтэс, blanket ијбортэт, and diapers тебеть. For a mattress, a hay-filled linen sack was most commonly used. Amulets played an important role: like the Udmurts, the Besermian kept scissors, a knife and iron objects in the cradle (Chernykh 1996: 295). The amulets protected the child against the evil eye and against being exchanged by the house spirit, or Shaitan. Analogous amulets are kept in babies' beds or strollers even today. 


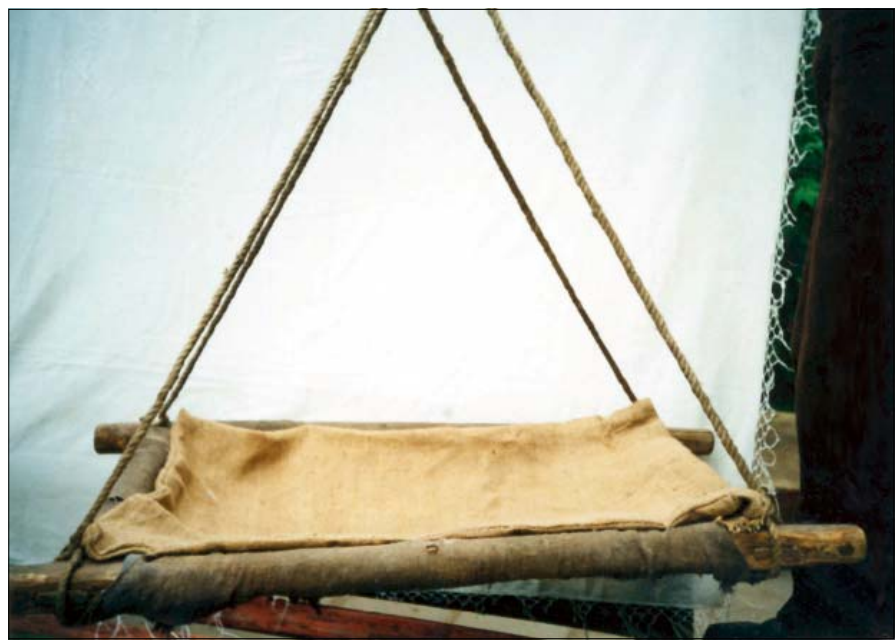

Figure 2. Cradle with a wooden structure. Collection of the Glazov Institute of Pedagogy. Photo by the author.

Women usually continued with their household duties already in the first few days following childbirth, and partook in field chores far away from home, in the field or woods. To be able to take care of and nurse the child, women took it along. Children were carried in various specially designed rucksacks. Infants were carried around in мушко, a cradle made of birch bark and woven and sewn of bast, with shoulder straps. For protecting the child against insects, rain and sun, the cradle was covered with a thick linen spread. According to older informants, the spread was usually decorated with special embroidery and applications. Whether the ornamentation served as a protective measure, or was only for decorative purposes, could no longer be determined. On these items that the author managed to see during the expedition, the embroidery had been lost. Often, a women's apron was used as the spread.

Hыnьет оr ныпи was sewn from thick square piece of cloth and had two shoulder straps. The child was seated there and worn on back with the child's legs hanging on the sides. Psychologically, the child 


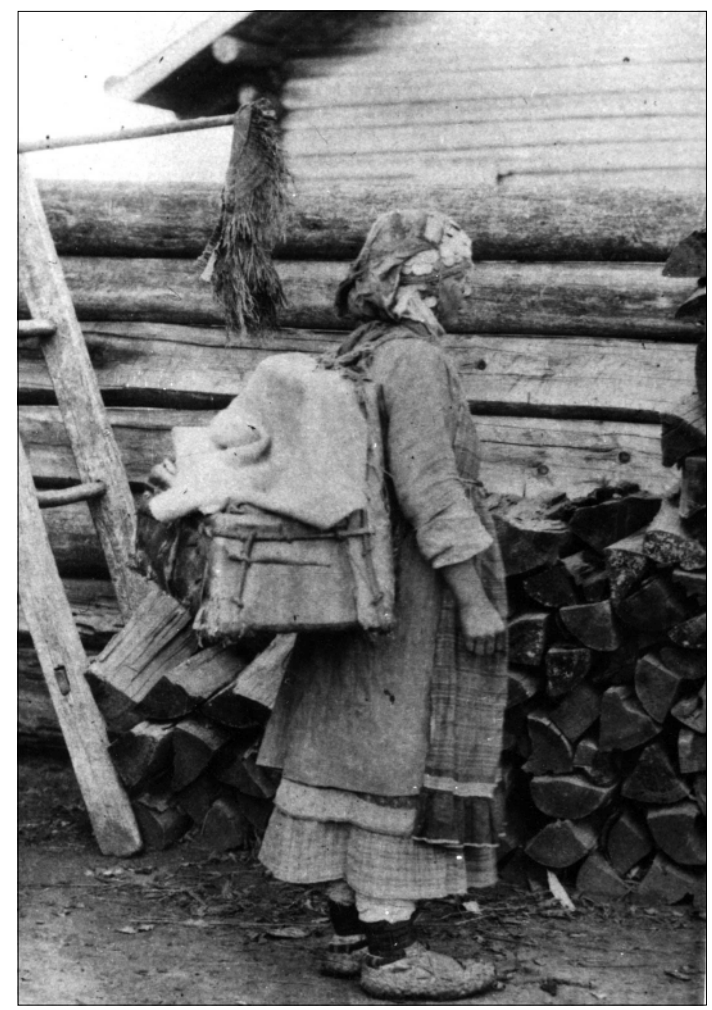

Figure 3. A Besermian woman with cradle мушко. Glazov District, early 20th century. Collection of the Russian Museum of Ethnography, no 354-100.

must have been comfortable, being so close to its mother, but the unstable soft seat may have been bad for its underdeveloped bones and backbone. Owing to this, a child was seated in a ныпи only after it could sit and crawl on its own, as it was believed that by this time its body had developed physically. A similar item was used among the Udmurts, who decorated it with bright interlaced bast. The Besermian Hunbem had no ornaments.

Infants who could sit and crawl were seated in a special chair called гјркес, which was hollowed out from a tree trunk and had a traverse board inside. The first steps of a child were observed particularly 
attentively. The child was encouraged to walk by means of a special walking chair with wheels - пинял вельтон колеса 'wheels for walking': the child held on to a crossbar and pushed the chair in front of it. When the infant took its first steps or stood up for the first time, nobody was allowed to startle the child, and the child was carefully observed to avoid its falling. If the child happened to fall, was startled and began to cry, some salt water was sprinkled on the spot on which it fell, a nail was driven in the floor, or someone spat there three times. This was done to protect the child against possible illnesses caused by the fall, and prevent the child's startling from interfering with its learning to walk. The Udmurts observed a similar custom (Vereshchagin: Arkhiv RAN, 135, op. 2/ 79: 49). These Besermian and Udmurtian rituals were associated with the beliefs that whenever a child or a grownup fell, there was a reason - they were either drawn by the "place" or disturbed by кӧж, the spirit of illness.

A separate group of taboos and beliefs is connected children's clothes, especially to designing, wearing, keeping and washing the clothes. Unfortunately, no complete example of children's clothes has been survived. While traditional clothes were usually carefully preserved in many families, there are little extant baby and children's clothes. This may be explained by the fact that the clothes were handed down from generation to another and were quickly worn out. Senior Besermian can still talk about the characteristics of children's clothes, and there are a few extant photographs. In this article I will present only a short overview of children's clothes, mostly in association with childcare and amulets.

A complete set of underclothes and clothes was never prepared for a newborn early in advance. Diapers were sewn of old grownups' clothes, usually of shirts: either the lower part of women's shirts or the back part of men's shirts. To make sure that the child would have straight legs, it was tightly wrapped in and bound with a special wide belt пинял кертэт 'child belt'. Children's shirts were sewn of undyed linen or cotton home-woven cloth. The shirt had embroideries on the chest and back, the lower hem and sleeves were decorated with red ribbon with interlaced pattern, kumach, or printed cotton. This decoration also functioned as a protective measure. The cut of boys' and girls' shirts was the same, but they differed in length 


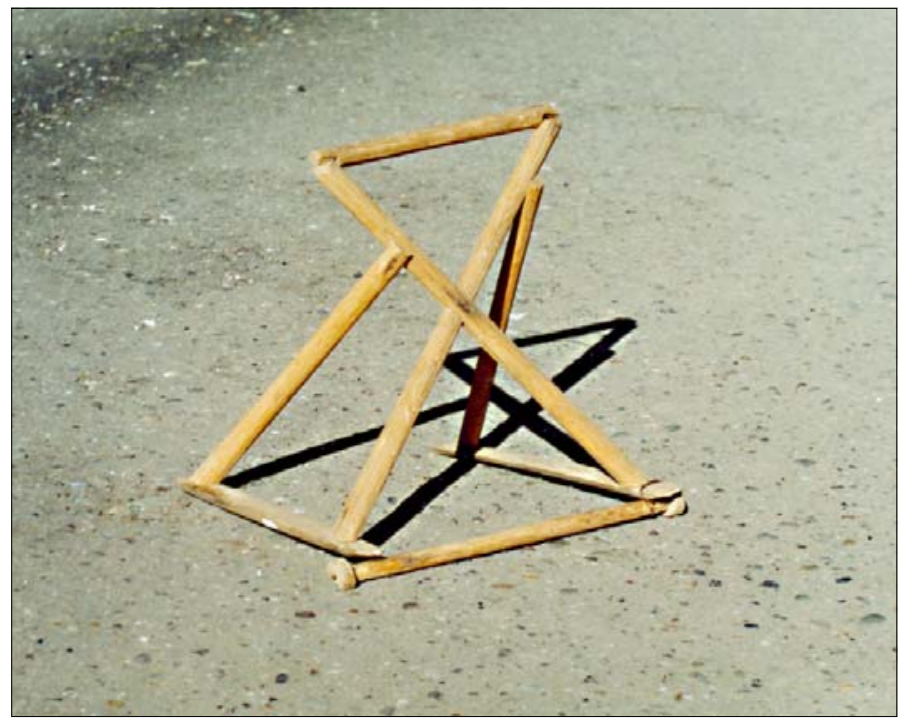

Figure 4. Walking chair. Glazov District, Kuregovo village. Collection of the Glazov Institute of Pedagogy in 1993. Photo by the author.

and ornamentation. A girl's shirt was usually not lined, and when the child grew, additional frills or ruffles were added. Children's clothes were embroidered with home-dyed inexpensive linen and wool yarns (VEM collection, 1111-55; 56; 57), whereas the clothes of grownups were always meticulously embroidered with high quality silk threads. Both boys and girls wore linen pants of specific cut, called пјдэстэм штан, or 'bottomless pants' (VEM collection, 111158). The pants were left open in the crotch area until the child learned to control its bowel movement. Pants of this cut were used as late as in the mid-1960s.

Children's headwear, like other parts of clothing, had, without exception, amulets against the evil eye attached to it. According to ethnographer T. A. Kriukova, a hat with an amulet of cowries and a bun of goat's beard attached to it was placed on the newborn baby's head by midwife. Later, when childbirth took place mostly in hospitals, a child was given such a hat by its paternal grandmother (VEM 
collection 7599-16). Goat hair was sometimes replaced with dog hair. V. N. Belitser has mentioned that among the Besermian, cowries as amulets were sewn to the forehead of caps even as late as in the 1930s (Belitser 1947: 190). The hat of a breastfed child was usually sewn of fine home-woven linen, or coloured strips of factorymade cloth. Amulets like metal objects, buttons, pearls, coins, were attached to the hats. A goose's tail (down) feathers served as amulets and also decorative purposes. The feathers were dried, sprinkled with flour and sewn in a row or a bundle to the hat. In modern times, the traditional amulets like cowrieshells, down feathers or pieces of leather are used mostly in families with ill and weak children. In recent years, the traditional amulets have been replaced by pins, brooches and badges.

The hats of older children were more complicated in design. From the age of four until their teenage years, girls usually wore пичи такъл, a small такъл. A detailed description of the hat is provided by N. P. Steinfeld from Viatka:

Small girls wear round-shaped hats which look like tubeteikas, or cull-caps of Tatar men. The hat is rimmed with a narrow braid or coloured ribbon, the hat itself is made of red woollen cloth, it has a thick lining, it is completely round and covers closely the girl's head. Two or three rows of small silver coins are sewn to its front, stretching from one ear to another. (Steinfeld 1894: 234)

This type of headwear can be found only in the collection of Russian ethnographical museum in St. Petersburg, which displays a home-woven cap with linen lining and a triangle of cowrieshells, large porcelain buttons, coins and round tin plates stretching from the cap's forehead to the top of the cap (VEM collection 1111-54; 6598-3; VEM photo collection, 1132-13). Towards the end of the 1930 s, this type of hat is abandoned from use. More recent versions are similar in cut, but lack the lavish ornaments. A children's hat called тупи оr тупик worn in the $1960 \mathrm{~s}$, for example, resembled такъя in shape, and was often called that, but lacked the ornaments. Tynu is a hat sewn from a rectangular piece of linen or printed cotton, which was sewn together at the back of the head. Some mynu were knitted from black yarn, rarely also from white yarn, for boys and coloured yarn for girls. Girls' headwear often included bright-col- 


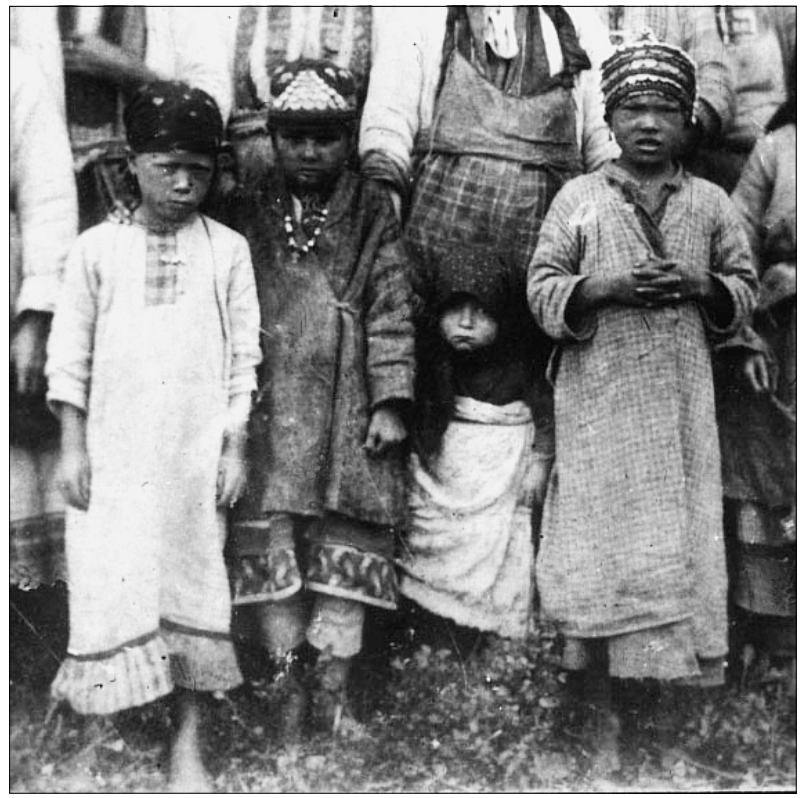

Figure 5. Children in the Shamardan village, Glazov District. Fragment of a photograph from 1906 by Zelenov, Photographic archives of the Russian Museum of Ethnography, no 1132-14.

oured headscarves, while boys often wore hats similar to those worn by adult men.

Rules concerning the washing, drying, and keeping diapers and clothes, form an entirely separate group. It was not allowed, for example, to wash or rinse babies' clothes in springwater or river. This rule was connected with a belief that one of human souls, ypm, is taken away with the current, and the baby will surely fall ill (AFM 1995: A. N. Baltacheva (born in 1937), Z. I. Baltacheva (born in 1929), Iukamen District, Tylys village; AFM 1993: I. K. Malykh (born in 1906), Iukamen District, Zhuvam village), and also with a belief that while washing the child's clothes in the river, the clothes might be contaminated with diseases in the river water. The clothes could not be turned inside out while washing, hung outside to dry, leave outside the house overnight, or the evil spirits and spirits of diseases might go into these. It was believed that evil spirits, who live 
outside, are particularly active in the nights, which is why nighttime was considered a dangerous time. The evil creatures reached the child through its clothes. The prohibition of rinsing babies' clothes in running water and hanging the clothes to dry outside the fence is still followed in some families.

In everyday life, the rules that were concerned with possible harm to the child's personality, behaviour and fate were strictly observed. For example, it was forbidden to put kitchen utensils, especially sieves, on one's head during play, as it was believed that a child will become short. An infant was not shown a mirror, otherwise it might sleep restlessly. Also, a child was not allowed to look into fire, for fear that it might start wetting the bed. Prohibitions also involved food - children were not allowed to eat ram's head, or they might get lost in the woods in the future; and whoever ate too much egg yolk, his or her skin was believed to turn yellow.

The basic food of infants was breast milk, and since feeding was irregular, the child was fed when it was hungry or cried. Breast milk remained a child's basic food until it turned two or three years old, or until the next child was born. Women were often already working in the field or in the woods, which made regular feeding very complicated, and the child was soon given additional food. When the baby turned two or three weeks old, it was given some bread dipped in milk or cream with honey and sugar, wrapped in a piece of cloth to suck. This was called нянь сосок, a 'bread teat', or басма сосок, 'rag teat'. Later the child was nursed on diluted cow milk. From the age of four or five months onward, the child was acquainted with grownup food, it was given porridge, chewed meat, boiled or grated vegetables. The rubber teats that were later taken in use were perceived as dangerous by the women of the older generation, as their use was believed to result in an incorrect development of the mouth cavity.

The lack of breast milk was considered one of the reasons behind the deterioration of a child's health, its slower development and growth. Losing breast milk was usually associated with breast diseases and casting an evil eye. It was therefore not advisable to boast with sufficiency of milk, or nurse a child in the presence of strangers. A breast illness of a nursing mother was always associated with the influence of ancestors among the Besermian (Zelenin 1916: 
43). The loss of milk was also explained by the woman's falling out of favour of the house spirit. If there was a reason to believe this, the house spirit was sacrificed bread and butter. Nursing mothers also acted as wet-nurses when someone had little or no milk.

The most important events in a child's life were teething, especially the appearance of the first deciduous tooth, the child's first steps, the first time its hair was cut, and the first time it left the house. These events were considered rather dangerous, it was believed that these determined the future development of the child, and this also necessitated the performing of complex rituals that have been well preserved until now in the restrictions and rules associated with childcare.

The emergence of the first tooth was celebrated with a present: whoever noticed the tooth first was called пинь шедьтьсь 's/he who found the tooth'. This person gave the child a shirt or a spoon as a gift, and received a small gift or some food. The exchange of presents was believed to secure the faster teething and the child having strong teeth in the future. Special rituals were performed on the lost deciduous tooth нонэм пинь оr йјл пинь. The child wrapped it in a rag or a piece of bread and threw it over the shoulder to the roof, or sometimes hid it in a crack in the wall. Sometimes the tooth was thrown in the doghouse, or to mice under the stove, who were asked to give a new and stronger one instead. Among the Besermian living upstream the Lema and Lekma rivers (in Ezhevo, Shamardan, Ezhevski Pochinok, and Ust-Lem villages) it was forbidden to throw the deciduous tooth to the animals, for this was believed to make the child quarrelsome with others like cats and dogs and his or her children might be later born ugly or with some physical disability. For this reason, in these villages the deciduous tooth was hidden only in cracks in the walls of the house or outbuildings to guarantee that the tooth would not be accessible for cats or dogs (AFM 1996: T. I. Volkova (born in 1924), Iukamen District, Ezhevo village).

When the child turned one year old, its hair was cut for the first time. It was forbidden to throw the hair outside for fear that a bird might take these to its nest and the child would get headaches and turn ignorant or foolish. The cut hair was mostly preserved or burned, as was a custom during the following hair cuttings. 
While taking the child outside for the first time, a mark was made on its forehead with flour or soot to protect it against the evil eye. Those who were encountered on the way were not allowed to praise the child, look at it, or discuss its health. Whoever happened to violate this rule, was supposed to spit three times and say out loud: "Let not the evil eye be cast!", or "Let not me be the source of evil eye!" This was done by all who came to visit the mother or the newborn.

Many rituals connected with curing and prevention of diseases and the critical events in the child's life were performed at home, and formed a part of family tradition. More serious children's diseases were treated by midwives and healers, who made use of rich folk tradition, rational and magic treatment methods. This required advanced knowledge about the mythological reasons of illnesses and traditional beliefs. The aim of most preventive and healing rituals was the preservation of the child's health and expelling the spirit of disease. It was believed that the supreme god Inmar watches over the fate and health of children. Inmar's will determines whether a child is healed or not. If the child is supposed to heal, it will heal no matter what, if not, then it will die regardless of all attempts to cure it. It is possible that this is why it was said: "Inmar took the baby!", "Inmar gave the child, Inmar took!", "Inmar would not let the child to live in this world!" This does not mean that the child's parents would not do everything they could to fight for the child's life.

Preconceptions of placenta as a protector of humans play an important role in folk medicine. It was believed that a placenta that was incorrectly or carelessly buried, turned a baby restless and brought nightmares. Various eye diseases and some dermatological diseases were also associated with placenta. If an illness was associated with placenta, and it was considered the only possible measure, some melted butter was sacrificed in the cellar on the spot where it was buried. The spot was cleaned of debris and some melted butter was poured on it. The placenta was then addressed with a prayer of the child's healing, reminding it that the placenta was supposed to protect and look after the child. After childbirth, placenta was carefully washed, wrapped in a white sheet, placed in an old birch-bark shoe and buried in the cellar. If the placenta's "peace" was disturbed, 


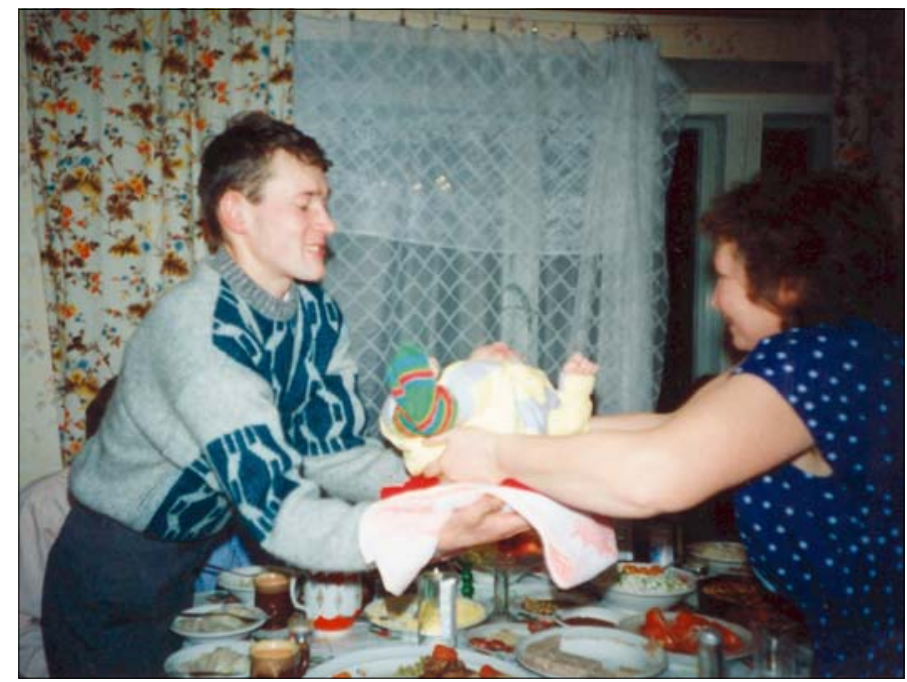

Figure 6. The ritual Christening of a child at home. Glazov. Photo by the author.

or there was debris on the spot under which it was buried, it was considered to be the main cause of illness. In modern times, the Besermian women give birth in hospitals, and placenta is no longer buried in cellars, but it is still believed that the health of infants may be affected by buried placentas of children who had been born in the house previously.

Traditional treatments and preventive measures were associated with concepts about the reasons of illnesses. All diseases were divided in two - internal diseases кет пуш висён, and heart diseases сюлэм висён. The former were explained by casting an evil eye and sorcery, but heart diseases were sent by departed ancestors (UIIJL archives, 2N/391, 1. 106). It was also believed that all diseases, except for injuries from blows and cut-wounds have been sent by лулъёс, spirits of diseases, who demand sacrifice (UIIJL archives, 2N/391, 1. 100). To keep diseases out of the house, amulets, mostly sharp objects like a knife, axe, scythe, sickle, were placed under the threshold. It was believed that in fear of cutting itself with a sharp object, the disease does not dare to enter the house (AFM 1993: I. K. Malykh (born in 1906), Iukamen District, Zhuvam village). In case of epi- 
demics, the house was circled with a religious icon, ground was ploughed around the village, and a bypass road was made for the passers. People feared that "if a sick person passes the village, the disease is left on the street, and the disease later enters the house" (UIIJL archives 2N/391, 1. 102; AFM 1991: K. A. Nevostrueva (born in 1924), Zhuvam village; K. I. Karavaeva (born in 1915) Iukamen District, Shamardan village). A disease brought in from outside had the most devastating effect on the most vulnerable in the house the child. This belief was associated with a rule that visitors from distant areas first touched the oven and only then entered the child's room. The same custom was observed by the Udmurts (Vladykina 1992: 134).

During an illness, the restrictions of household chores and certain rules of behaviour were observed in order not to infuriate the spirit of disease or harm the child. A child's clothes, for example, were never rinsed in running water, so that the soul ypm would not leave downstream. Clothes could not be soaked in lye; it was forbidden to clean chimneys, wipe off soot, or clean. Family members were not allowed to argue, call each other names, or hit domestic animals. Also, it was forbidden to kill animals and birds when a member of a household was ill. It was believed that a violation of these rules might infuriate the spirit of disease and this, in turn, might slow the recovery of the ill person, or lead to his or her death.

The spirits of disease, fever and any disease accompanied with fever were called пер ог висен пjр. The same word was used by the Udmurts, who, according to G. E. Vereshchagin (Arkhiv RAN, 135, op. 2/ 79: 47) referred to typhoid or fever by this term. It was believed that the spirits of disease had to be fed and welcomed in the house with respect. Only then will they leave voluntarily and the person will be healed. Sometimes, the disease might have left before the child was cured, therefore a serious illness or complication was explained by the leaving of the spirit of disease, nep, itself. It was believed that nep might leave with visitors or family members, which is why the child was never brought out to say farewell to them, and the child was also never taken near a window or a door. The observance of these obligatory taboos and hospitality towards the spirit of disease secured a mild course of disease and a speedy recovery. 
If the cause of the illness was attributed to the departure of nep, a ritual called пер йббръян 'sacrifice to пер spirit', оr пер коноятон 'offering food to nep' was performed. The ritual was sometimes even referred to as пер коно 'reception of пер', and the spirit of disease was treated like an important visitor, who was received according to the prescribed etiquette. The ritual was performed by a female healer, sometimes an elderly woman, who had to be proficient in the ritual. It was believed that a single mistake might have made the child's condition worse, as nep might have refused the invitation and not return. The earliest record of the ritual can be found in the Besermian texts by Y. Wichmann. Wichmann has recorded a prayer that was uttered at the gate while holding a white tablecloth, bread and butter. A female healer bowed three times in different directions and addressed the diseases with the following words:

Don't be angry! Don't be offended! Come, come, dear guests! How have we offended you? Don't be angry! We prepared you a good meal! Come, stay with us! Perhaps we quarrelled and argued? Perhaps we called our dog names? Perhaps we called our cat names? Don't be angry! Come, come, guests! Let us live together! Give Vassili [the child's name - the author's note] back his health and spirits! (Wichmann 1893: 168)

Fieldwork material indicate that there was no specific formula that was used to address the spirit. An improvised summoning usually included the listing of reasons which may have offended the spirit of disease: an argument between family members, violation of restrictions of working, offending domestic animals, etc. The invitation included a prayer to come and forgive the trespassing of rules. Here is another text example, recorded in one of the recent expeditions:

Our child's пер left! It left, when clothes were rinsed! So we are summoning пер back! We argued at home, but don't be angry! Let your return bring health to him [the child - author's note]! Let our child be healed! Let him eat and drink again! (AFM 1991: N. K. Nevostrueva (born in 1919), Iukamen District, Zhuvam village)

Having addressed the spirits of disease, the woman returned to the house but left all gates and doors open so that the spirit would be 
able to come in. Sometimes the ritual was performed in the house at an open door. The tablecloth, where bread and butter were placed during the ritual, was spread next to the sick child. Then, nep was summoned at the table and the family sat down to eat. On this occasion, barley meal porridge with meat broth, or a mixed porridge of pearl barley and peas was served. It was quiet at the table, as it was believed that nep was present and shared the meal with them. During the ritual and the ritual meal, the family members could not leave the house or visitors enter, otherwise nep, the spirit of disease, would leave again. It was forbidden to perform dirty, muddy or noisy chores, borrow food or things, or for strangers to approach the child before the sick child had fully recovered. All these precautions were explained by the possible offending and leaving of nep. These customs are still observed in some families when children are seriously ill.

Formerly, it was fairly common to believe that in case of illnesses of children and adults, the spirits of disease have to be fed, received and sent away like welcome guests. It was believed that the spirits "get hold of" humans mostly while in search for food. N.V. Nikolski describes that the Besermian placed a bowl of "different kinds of pastry and butter, in order to feed the disease and make it merciful" (1919: 77) on the window. Entering the house of someone suffering from typhoid fever, a loaf of bread was taken along to feed the illness, to prevent the disease from coming along afterwards (UIIJL archives, $2 \mathrm{~N} / 391,102)$. In case of measles пужы and smallpoх чача, melted butter and salt was kept on the table covered with white tablecloth, so that the disease would not be hungry and "devour" the ill person. Outside the village or at the village gate, a twig split in three with pancakes, porridge and strips of cloth was placed (Nikolski 1919: 78). The Udmurts took such a twig to the edge of the village during epidemic diseases (Vladykin 1994: 136).

The Besermian believed that the dead influence the health of the living, especially of children. Insomnia, some mental illnesses and the melancholy of children was explained by the wrath of ancestors. If a child slept restlessly, some grains, flour, salt and small coins were wrapped in a piece of cloth, taken outside the borders of the farm and sacrificed. Sometimes, a single object for sacrifice was enough, but it was always wrapped in cloth and cast towards north 
by saying "May [the ancestors] bring sleep, sound sleep. May they bring good and light night sleep" (AFM 1996: T. I. Antuganova (born in 1924), Iukamen district, Ezhevo village).

In case of a long and serious illness of a child, an elderly woman was asked to perform a sacrifice in a special place вей киськан 'the site where you pour butter', or вей киськан куала 'the site of pouring butter'. The obligatory accessory of the sacrifice was melted butter, which was poured on earth floor, or into a small cup. The woman addressed the ancestors, praying for health for the child (UIIJL archives, 2N/391, 1. 72). The number of such sacrificial buildings corresponded to the number of families in the villages, though when sacrifice was in order, each family went into their own kuala. Since the late 1960s, collective prayers were no longer held, and the kualas gradually deteriorated. Later, the sacral functions were returned to the former places of sacrifice. In some villages, a fence bordered the sacred area, in others they were hidden by trees and shrubs. Nowadays, in case of serious children's diseases, which are believed to have been caused by the ancestors or куала, butter is sacrificed in these places.

A child's psychological and physical health was also influenced by its spiritual situation. The Besermian believed that an individual had two souls - лjл and ypm. Sickly feeling and mental disturbances were associated with the departure of ypm because of disease or startling, which happened most often to children. The leaving of ypm was both the cause and consequence of the disease and may have led to death, unless the soul returned. If the second soul, лjл, left a person's body, it was popularly believed that this would lead to death, because the soul could not be retrieved. Studies reveal that in folk medicine, the retrieving of ypm was very commonly practiced, though only by highly experienced healers.

The ritual of the retrieval of ypm was called урт этен, 'the invocation of ypm'. A female healer went outside the gate with a white tablecloth or scarf, as well as bread, salt, butter and the clothes of the sick child ("so that the soul would find the child by its clothes"). She searched for the soul in the garden, outside the gate, in the sauna and other outbuildings, bowed, and asked ypm to return to the child. The area outside the outbuildings and behind the gate served as a border between familiar and unfamiliar; and the soul 
could be found there. The healer took some grass, debris and splinters back to the house, believing that these will make ypm to return. The items and the child's clothes were placed next to the child's bed, and the tablecloth was laid out next to the table. Members of the family bowed three times towards the cloth in order to invite ypm to accept the meal consisting of bread, butter and tea, laid out at the honorary seat on the table. The family sat down for meal only after taking bows and inviting ypm to share the meal (UIIJL archives, 2N/391, 1. 106-108). The ritual shared local characteristics: The Besermian of the Gordino village prepared barley meal porridge in a broth made from ram's or sheep's ribs. This was explained by the belief that the soul ypm resides inside a person, between the ribcage.

This ritual is associated with treating startling. As already mentioned, startling someone may have resulted in the leaving of ypm. If a child was startled by an animal or bird, he or she was smoked with the hair of the animal, or the feathers of the given bird. The child startled by a bird was bathed in water, to which cinders of feathers and spiderweb was added. This was always done in the middle of a room, directly under the girder. Unless the child startled by a dog could be treated with the traditional method, the disease was called the dog's illness пјнј кјль and the child was "baked" in the oven. The ill child was seated on a pan or a shovel, and was held in front of the oven mouth, and it was said: "I will stick it [the child - author's note] in the oven. Let the dog's startling pass, let the cat's startling pass. Let the startling pass and let the disease go out through the chimney" (AFM 1993: I. K. Malykh (born in 1906), Zhuvam village).

Among the more serious children's diseases belonged a form of casting the evil eye called пож киён-пјдјн сюдемјн 'he who is fed with dirty hands and feet'. The disease was associated with touching the child with hands unwashed after sexual intercourse, as a result of which the child turned pale, weak and lean. The illness may have ended fatally, but even if the sick child recovered, it remained weak and was often ill. The child may have been infected by a man who had had physical relationships with many women. Such men were not allowed near a small infant, or were not allowed to hold one. The Besermian beliefs about the impurity of humans after sexual intercourse are analogous to the Komi beliefs about nеж, a special 
condition caused by intercourse, which is harmful to people, infects others, especially children and is transferred by physical contact (Nalimov 1991: 6, 18). The Besermian believed the disease to be incurable and always performed a new ritual of "having" the child, or "giving birth" to the child, imitating labour. The ritual was performed in the sauna. The mother of the child was expected to imitate painful labour and the healer lifted the child three times from between her legs. During the ritual they held a dialogue: the healer asked the woman "in labour" what will it be. And the woman had to answer, depending on the sex of the child, which was it, either a boy or a girl. The child was given a new name. Even in the 1950s many Besermian were known by two names: the second name was unofficial and was not written in documents. The villagers, however, usually knew the person by his or her unofficial name. Nowadays, this custom is remembered only by healers who treated children, and the elderly women who participated in the ritual. According to the informants, the ritual has been rarely practiced in the past two decades, and many people who are not aware of this illness treat it as the casting of evil eye or witchcraft. And even if the ritual is performed, the second name given during the ritual is not generally used in the future.

Among the most common children's diseases was синь усен, another form of casting the evil eye. In this case, the child cried a lot, its sleep became restless. The child was protected by the use of amulets attached to the headwear, shirt fronts, neck or wrist. For example, an iron object, a thread woven of juniper, or a thread spun counter clockwise was tied around one's neck; a red yarn or thread was worn around one's wrist. Different treatment methods included the "washing off", "steaming out" or "burning" of the cast spell. The child's face was washed with water, which had been previously used for washing the door handle and corners of the table. Spring water, brought in the house before sunrise, was specifically used for treating the influence of the evil eye. Particularly effective for treatment was the water brought in on Maundy Thursday, or water gathered from three springs at morning or evening twilight of any Thursday. An iron object was placed in the water and the container was then covered by a lid or a towel so that the evil spirits or Shaitan would not corrupt it on their way home. Water used for treatment was always kept sealed and away from doors and windows. In the 
mythological conceptualisation of many cultures, windows and doors are viewed as the border with the outer world, which is perceived as a particularly dangerous place, and with a special semantic tension (Baiburin 1983: 135). The Besermian regarded the windows and doors as passages through which illnesses and Shaitan entered the house, and therefore, water was kept in the kitchen under the bench, or behind religious icons in the altar corner. Before use, it was slightly warmed up but not brought to boil, or the water may have lost its healing quality. The healing quality of the water was enhanced by spells consisting of several analogous short prayers for destroying the curse of the evil eye. For example, "Let the water remove the evil eye and magic! Let it take the yellows and the greens from him who cast the evil eye! Let this cure the child!" (AFM 1993: F. I. Nevostrueva (born in 1907), Iukamen district, Zhuvam village). To further intensify the curative effect, the child's face was washed in the middle of a room under the girder. The curse was treated also with dew gathered on the morning of Midsummer Day. In families with sick children, this dew water was preserved through the entire year. Dew was gathered by means of a towel of cloth which absorbed dew and was then squeezed in a bowl. For the same purpose, fire was used, which was supposed to "burn" the evil eye that caused the disease. The child was seated under the girder and three circles were drawn in the air with a pinch of salt. The salt was then thrown into the fire and it was said: "Let his [the curser's - author's note] eyes be burnt! Let this bring health to our child! Let the fire burn the evil spell!" (AFM 1993: N. S. Malykh (born in 1918), Iukamen district, Zhuvam village).

Among the common beliefs the most dangerous mythological characters for a child were the sauna spirit Мунчо кузё, the forest spirit Чашша кузё, the house spirit Корка кузё, who all caused illnesses and helped to treat these. The author's fieldwork results indicate that these conceptualisations have remained relatively stable in folk medicine and everyday life over the recent years.

The most problematic spirit was the house spirit, who may not have accepted the newborn child. This may have happened when there had been no children in the house for a long time and the child's appearance was seen as an intrusion of a stranger. It is not known whether there used to be a special ritual to acquaint the newborn 
to the house spirit, but in the early 20th century, a sacrifice to the house spirit Корка кузё was performed on the occasion. A sacrifice was left to the house spirit on an improvised table in the cellar. A small splinter covered with white cloth was set up between beams. The splinter served as a table and the cloth as a tablecloth on which a sandwich (UIIJL archives, 2 N/391, 1. 10), sometimes some porridge, or an egg pancake was placed. During one fieldwork expedition the author managed to witness a modern ritual, in which the child was presented to the house spirit: after the child was brought home from the hospital, the child was taken to the entrance of the cellar, and the house spirit Корка кузё was asked not to offend the child while swaying the child. Then the child's name was said and it was presented as a new member of the family, who from then on was going to live in the house.

If the house spirit was believed to frighten the child, a sandwich was taken to the cellar and placed on the earthen mound in the southern part of the house. The same ritual to Корка кузё was performed while praying for help on the occasion of serious children's diseases. If a healthy child began to cry a lot and became thin, it was believed to be possessed by Корка кузё, or the latter has replaced the healthy child with its own child. In order to get the healthy child back, the child's shirt was left in the cellar overnight and in the morning it was placed next to the child's bed. On other occasions, a female healer took the child to the cellar and asked the house spirit to return the right child. The same custom was known among the Udmurts (Maksimov 1926: 88). The Besermian of the Gordino village performed the ritual of having a new child: the child was bathed in the cellar in river water and the healer passed it through the hames to the child's mother. This ritual symbolised the rebirth of the child to its former value, and did not only symbolically destroy the disease but resulted in the return of the child. This tradition has been known in various forms among many peoples and symbolised rebirth, whereas the hames functioned as the womb (Ilina \& Shabaev 1985: 118).

An unfamiliar house spirit, who strongly disliked strangers, was considered particularly dangerous for a child. This is why an infant could not be taken to other people's houses or visit acquaintances. If the disease was believed to be caused by other people's house 
spirit, the child's clothes were taken to the cellar of the house, which had been visited with the child. In the morning the shirt was returned and placed in the bed next to the child's head. In such an occasion, the Besermian on the upper course of the Lekma river (in Tylys and Gulekshur villages) set the child's hat and shirt on crossed sticks and placed it next to the gate of the house that had been visited with the child overnight (AFM 1995: J. I. Nevostrueva (born in 1921) Iukamen District, Gulekshur village). In recent years, healing methods have been developed for incidents in which a child's illness was caused by the spirit of the hospital. If the spirit of the hospital did not welcome the child, the medical treatment might prove useless. For this purpose, before bringing the child back from the hospital it was advised to cut three small splinters from the floor boards, soak these in water, and wash the child's face with the water (AFM 1995: Z. I Baltacheva (born in 1929), Iukamen District, Tylys village).

If the child's health did not get better regardless of all the applied healing methods, and it was feared that the child might die, the ritual of "selling and buying" was performed. The child was "sold" for a nominal price to a person with strong health and kind personality, who left the house with the sick child, then returned a few minutes later and handed the child over to its parents by saying: "Let the child live at the expense of my happiness!"( AFM 1995: L. I. Diukina (born in 1932), Iar District, Vortsa village). Sometimes the sick child was "sold and bought" inside the house, at the table: the parents sold it to the godparents, a married couple. The fresh godparents gave the child a new name and handed the child back to the birth parents. The same tradition was known among other people along the Volga River (Atamanov 1985: 98; Fedianovich 1979: 84-85) and among Russians in some districts (Sumtsov 1880: 69). Depending on the gender of the child, the "buyer" was a man or a woman, who then became the child's godparent. The godparent was offered food and given a present (a piece of cloth, towel, scarf, or a shirt) and was treated like other godparents, though the latter were treated with more respect. This godparent was also attributed all the important functions of other godparents, including the right to participate in the godchild's wedding and family gathering, and be invited to the party held when the godchild was sent off to the army. 
In case of a gravely sick child, the Besermian performed a ritual of throwing the dust шакта вјлэ куштон. As in the "selling and buying" ritual, the parents invited a person in good health of the same sex than the child into their house. One of twins, if this was possible. Before the guest arrived, the dust wiped from the room was left next to the threshold, and the naked child was placed on it. It was believed that by taking out the dust, the disease was also wiped out. When the invited person arrived, the parents asked him or her to take the baby from the floor, share their health and become a godparent: "Take the child! Take away the illnesses of our child! Take the cries of the child. Be its godmother/godfather." The guest took the child in his/her arms and passed on to the parents, wishing good health: "Leave your illnesses and weakness! Be well!" The main purpose of the ritual was having a new and healthy child. Among the Besermian and Northern Udmurts, the person who participated in the ritual became the child's godparent and was extended all the norms and customs like in the previous case. After this ritual, the child's parents and godparents were allowed to call each other co-parents, as at Christening. While describing the ritual among the Northern Udmurts, N. G. Pervukhin correctly noted that this was an earlier custom than Christening, and the concept of coparents was adopted after Christianisation and "the Christian significance was attributed to those who were already known as such before Christianity was adopted" (1890:37). The rituals of "selling and buying" of the child and "receiving the child from the dust" are essentially very similar to the ritual of "rebirth". The main aim of the rituals was to replace the ill child with a new and healthy child, though, unlike the "rebirth" ritual, the two latter were performed at home without the help of a healer. Perhaps this fact explains why there is relatively sufficient information on these and the rituals persisted for a long time as a part of family tradition. The ritual of receiving the child from the dust was widely practised among the Besermian even in the mid-1960s, and is can still be encountered in families with elderly people.

A child who was constantly hungry and frequently asked for food was also considered ill. In this case the adults said that the food is no use and the illness had to be "hacked". The child was hidden under a wooden trough and a whisk was hacked on it, or it was just knocked with a knife or an axe. The child was told: "Look, how I will 
hack you under the trough, if you ask for food!" (AFM 1991: V. P. Popov (born in 1941), Iukamen District, Zhuvam village). It was believed that after "hacking" the child will be healed, the food is useful, and it takes exactly as much food as is needed for the child's normal development. The Besermian, similarly, "hacked" another disease like this - ачарвак. If an infant refused nursing, it was placed on knees, covered with a trough, which was knocked upon with an axe, and it was said: "Night returned, day returned, Sun returned, Moon returned. May the child be well: I will hack the child's ачарвак" (AFM 1996: T. I.Antuganova (born in 1924), Iukamen District, Zhuvam village). Among the Udmurts and the Komi, the ritual "hacking" of the trough was used for treating children and adults who were on their deathbed (Ilina \& Shabaev 1995: 118; Chernykh 1996: 295).

To avoid protrusion of the navel, or umbilical hernia, $\partial э и ̆$ or y сие, a child was not allowed to cry in loud voice, or excessively strain abdominal muscles. Children's hernia was treated with massage, pressing strokes with hand or small items with simultaneous inhaling. For example, making a cross-sign below navel while inhaling. But there were also other methods: a pinch of pearl barley was placed above the navel, some flour below the navel, some coal left of the navel, and salt right of the navel, and first the pearl barley was pressed, then flour, then coal and salt, i.e. a cross-sign was made again. Sometimes the stomach was massaged by light strokes with one end of spindle, rolling pin, the empty reel of the loom, or bridle bit. Also, three circles were made round the navel counter clockwise with the thumb or forefinger, and the stomach was rubbed in with tar used for millwheel. The maggot of bark beetle was placed next to the navel. The maggot bit the skin, which made abdominal muscles to contract. If the method made the child urinate, it was believed to be effective. The treatment of umbilical hernia on boys was sometimes performed by horse healers. It was also noticed that boys suffered more often from umbilical hernia than girls.

Up to today, the Besermian use various methods for treating stammering. This condition was considered congenital, or resulting from startling. The ill child was bathed in the sauna, where it was laid on its stomach, and the left foot was stretched towards the right hand and the right foot towards the left hand. It was believed that if the hands and feet were stretched enough to touch each other, the treat- 
ment might be effective. Then the child was hit with a whisk, and water was sprinkled behind the door, by uttering: "Let the stammering disappear. Let the child's stammer disappear behind the door." And, analogously to other treatments, the child's illness was transferred to a healthy adult. After bathing, the ill child was passed through the sauna window to an adult whose name it shared, and he or she was asked to take the illness away. The child's mother may have also called his mother to perform a specific ritual "feeding". The child was seated under the table and a bell was moved above the table. Some porridge or roasted oatmeal was poured in the bell and was given to eat to the child under the table. If the child's stammering was believed to be the result of startling at the water, or having fallen into the water, the child was believed to have been frightened by the family spirit of water Ву кузё. In this case, the treatment was performed at the riverbank. The bell was held above the child, and Ву кузё was addressed with a prayer not to startle the ill child. Then the child was fed porridge from inside the bell. In Turchino, Filimonovo and Istoshur villages, the ritual porridge was served from magpie's nest. The same was done among the Northern Udmurts on the right bank of the Cheptsa river. The serving from a bell or a magpie's nest was explained by the fact that the child was supposed to start speaking resoundingly and clearly, like the sound of the bell, or the noise of the magpie. It was thus attempted to give the patient the qualities of ritual objects.

In case of excessive salivation, the child's saliva was "cut" with scissors, or water was poured into the child's mouth by the yoke, and the child was bidden good health. While pouring the water, the pourer stepped on the sleeping bench, while the child was on the floor.

If the child suffered from bed-wetting, the illness had to be "pinched together" or "shut down". For treating the condition, the child was told to urinate on the gate hinge in the morning. Sometimes, a healer was called. The healer asked the child to urinate on three splinters, which were placed on the threshold with uttering some words, and the door was closed (AFM 1995: J. G. Zambakhtina (born in 1925) Iukamen District, Turchino village). Enuresis was explained by startling and the cutting of the umbilical cord too short at childbirth. The child might have also fallen ill when it stepped on a former site 
of sacred cult building вей киськан, 'the place where butter was poured'. If this was the case, the sacrifice of melted butter was definitely in order.

Health was protected and diseases were prevented also by the children's participation in certain calendar rituals. The most interesting of these was 'tying silk threads', or буртчинь керттон, on a Maundy Thursday. Early this morning, children visited relatives and neighbours. People whom they visited wished each child good health for the oncoming year and tied coloured silk threads and yarn around their wrists. These amulets were worn until Easter and the ritual marking the beginning of agricultural work. During this ritual, the threads were tied on a twig of fir tree, or a splinter, and were sent downstream the river by saying: "Let the water take away our diseases!", "Let the threads take our diseases!" In recent times, this ritual has been abandoned, and children send the threads off at debacle or throw the threads into the river or a stream a few days after the visits, or tie these on the branches of deciduous trees. In the latter case, the tree is later carefully watched. If the tree grows nicely, the child will be healthy, while the tree's drying is a bad omen. Before sunrise on Maundy Thursday, a small fire was made of straw and juniper twigs. All family members jumped over the fire, infants were taken across in arms, or were passed or held above the fire. Children suffering from illnesses, stammering or enuresis were definitely taken to the fire. The child was made to warm its hand over the fire, or step on the ashes. The ashes that were left from the fire were taken outside the village and were believed to take along all the illnesses. Recently, the ritual is mostly performed in families with sick children. Children were also whisked with willow twigs on Palm Sunday in order to expel all diseases and laziness from them. In folk calendar, all the customs and rituals associated with treatment and securing health for the following year were performed in spring.

The objective cause of many children's diseases lay, of course, in the then living conditions. As late as in the 19th century, priest K. A. Satrapinski told the (Udmurt and Besermian) members of his congregation that the diseases are caused by too light clothing, unsanitary conditions and coarse food. He wrote, "children suffer from various rashes, measles, chickenpox, scarlet fever, and, mostly in summertime and mostly caused by eating too much green vegeta- 
bles, diarrhoea" (Satrapinski 1854). Changes in living conditions and the establishment of medical facilities gradually put an end to formerly widely common children's diseases, especially infectious diseases like measles, chickenpox, typhoid fever, etc. This is why the popular treatments that were formerly widely practised among folk healers and adult family members were largely abandoned by the second half of the 20th century. Now, many former rituals are remembered only by the older generation.

On practical level, families still use some popular methods for treating the evil eye, startling, insomnia, colds, sores, festering wounds, and returning the exchanged child. Some prohibitions are still observed during children's illnesses, such as not taking things outside the house, or rinsing the ill child's clothes in running water. Until the middle of the 20th century, the knowledge about children's hygiene and care was only held by midwives. Later, when children were born mostly in hospitals, the midwives were called only on emergencies, if a woman in labour was unable to go to the hospital. The author's fieldwork results indicate that since the middle of the 20 th century, the role of midwives mostly included caring after and treating the newborn. They also bathed the child on first days after arriving from the hospital, corrected the shape of the child's head, massaged, and treated hernia, startling, and performed rituals against the evil eye and removing the "bristle".

Among the Besermian, midwives and healers treated also people outside their own village; they were often called elsewhere, including Russian, Udmurt and Tatar villages. Compared to their neighbours, folk treatment methods, especially those used for healing children, were best preserved among the Besermian. It is no coincidence that in the area densely populated with Besermian, they were considered good healers, sorcerers, and wise men experienced in magic. In mixed villages, children were often treated by Besermian healers. The explanation provided by informants interviewed during fieldwork was that the Besermian preserved traditional beliefs, culture and knowledge about folk medicine longer than the neighbouring cultures. It has to be noted that regardless of the generally well-preserved tradition, the knowledge of midwives and healers was not as well-preserved as the treatment methods practised in the family circle. This explains why knowledge about treating the 
consequences of sorcery and children's hernia, rituals associated with nep, the spirit of disease, or retrieving the soul ypm, having a new child, or other complicated conditions and treatments that root in mythology, have largely been forgotten. The older generation, who still remembers this part of tradition, is not involved in treating the diseases, not to harm the child even more.

The methods used for treating and prevention of children's diseases were similar to these used for treating adults, though there were characteristic differences. The latter was associated with age differences and beliefs that children were weaker and more helpless. Many treatment methods took into consideration the view that children were in the borderline position, thus, the ritual of retrieving health from an adult and the "rebirth" of the child played an important role in the tradition. Quite a number of customs and rituals are associated with infancy, especially the first postnatal months, since these determined the child's health in the future. It is worth emphasising that the contemporary methods of treating children entail former rituals widely practiced at treating adults. Having analysed methods used in folk medicine, it can be said that these are analogous to the treatment and healing methods of the Udmurts. Possibly, this similarity is largely caused by common elements in the shared economic situation and lifestyle, shared beliefs, mythological conceptions about the surrounding world, and the position of children in this. Analogies in the paediatrics of peoples of the Uralic and Volgaic regions may also be explained by similarities in climatic and socio-economic factors, which laid the foundation for the development of ethnic diversity.

In conclusion it is worth noting that the traditional methods of treating children's diseases and childcare, especially those associated with giving birth and the first year of a child's life, continued to be a part of family tradition. Many rituals still followed constitute a complex of obligatory knowledge in folk medicine, shared by folk healers and ordinary Besermian rural families alike.

\section{References}

Atamanov, Mihail G. 1985. Obriady i poveria udmurtov, sviazannyie s imenami [Name-related beliefs and customs among Udmurts]. Grishkina, 
Margarita V. \& Maier, Vilgelm E. \& Khristoliubova, Liudmila S. (eds.). Semeinyi i obshchestvennyi byt udmurtov v XVIII-XX vv. [Family tradition and social order among Udmurts in the 18th-20th century]. Ustinov: NII pri SM UASSR, pp. 91-106.

Baiburin, Albert K. 1983. Zhilishche v obriadakh i predstavleniakh vostochnykh slavian [Edifice in the customs and belief of eastern Slavs]. Leningrad: Nauka, Leningradskoe otd-nie.

Belitser, Vera N. 1947. K voprosu o proizhozhdenii besermian (pomaterialam odezhdy) [On the origin of the Besermian (based on clothing)]. Trudy instituta etnografii imeni N. N. Miklukho-Maklaia. Novaia seria, 1. Moscow: Izd-vo Akademii nauk SSSR, pp. 183-193.

Chernykh, Aleksandr V. 1996. Obriady i poveria, sviazannyie s rozhdeniem rebionka $\mathrm{u}$ kuiedinskikh udmurtov [Customs and beliefs related to childbirth among Kudinsk Udmurts]. Saveleva, Eleonora A. et al. (eds.). Khristianizatsia komi kraia i ee rol v razvitii gosudarstvennosti $i$ kultury [Christianisation of the Komi region and its influence on the development of the state and culture], 1. Syktyvkar: Komi nautchnyj centr UrO RAN, pp. 291-296.

Fedianovich, Tamara P. 1979. Mordovskie narodnyie obriady, sviazannyie $\mathrm{s}$ rozhdeniem rebionka (konets XIX-70-e gg. XX v.) [Traditions relating to childbirth among Mordvins (from the late 19th century to the 1970s)]. Sovetskaia etnografia, 2, pp. 79-89.

Ilina, Irina V. \& Shabaev, Yuri P. 1985. Bania v traditsionnom bytu komi [Sauna in Traditional Komi Lifestyle]. Trudy Instituta iazykak literatura $i$ istorii, 32, pp. 109-119.

Maksimov, V. A. 1925. Votiaki: Kratkii istoriko-etnograficheskii ocherk [Votyaks: Short historico-etnographical overview]. Izhevsk: Udkniga.

Nalimov, Vasili P. 1991. K voprosu o pervobytnykh otnosheniakh polov $\mathrm{u}$ zyrian [About the initial attitude of Zyrians towards the two genders]. Konakov, Nikolai D. et al. (eds.). Semia $i$ sotsialnaia organizatsia finnougorskikh narodov [The Finno-Ugric family of nations and its social organisation]. Trudy Instituta iazyka, literatury i istorii Komi nauchnogo centra UrO RAN, Vyp. 49. Syktyvkar, pp. 5-23.

Nikitina, Galina A. 1992. Vozrastnyie tsikly v narodnoi pedagogike udmurtov [Age-related cycles in Udmurtian folk pedagogics]. Vestnik Udmurtskogo universiteta $=$ nauchno-publicisticheski zhurnal, 6, pp. 3946.

Nikolski, Nikolai V. 1919. Sbornik istoricheskikh materialov o narodnostiakh Povolzhia [Collection of historical materials of the Povolzhie peoples]. Kazan.

Pervukhin, Nikolai G. 1890. Eskizy predanii $i$ byta inorodtsev Glazovskogo uiezda: Sledy iazycheskoi drevnosti i suievernykh obriadakh obydennoi zhizni votiakov ot kolybeli do mogily [Sketches of legends and lifestyle among non-Russian habitants in Glazov uiezd: Relics of the 
pagan past and religious customs from cradle till grave in everyday Udmurt life]. Eskiz, V. Viatka.

Satrapinski, K. A. 1854. Votiaki i besermiany, prozhivaiushchie v prikhode i sele Ukan Glazovskogo uiezda [Votyaks and Besermians living in Galzov uiezd Ukan parish]. Arkhiv Russkogo geograficheskogo obshchestva. Razriad X, 1/48, p. 5.

Shabaev, Yuri P. \& Shabaeva, N. I. 1995. Bania v verovaniakh i predstavleniakh russkikh, komi i udmurtov [The sauna in the beliefs and customs of Russians, Komis and Udmurts]. Finno-ugrovedenie, 2, pp. 51-63.

Steinfeld, N. P. 1894. Besermiane: Opyt etnograficheskogo issledovania [Besermians. Etnographical study]. Kalendar $i$ pamiatnaia knizhka Viatskoi gubernii na 1895 god. Viatka, pp. 220-295.

Vladykin, Vladimir E. 1994. Religiozno-mifologicheskaia kartina udmurtov [The religio-mythological world view of the Udmurts]. Izhevsk: Udmurtija.

Vladykina, Tatjana G. 1992. Udmurtskie poveria $\mathrm{v}$ sisteme etnosotsialnoi reglamentatsii [Udmurtian beliefs in the system of etnosocial reglementation]. Nikitina, Galina A. \& Trofimova, Elena I. \& Shkliaev, Georgi K. (eds.). Traditsionnoe povedenie i obshchenie udmurtov. Izhevsk: Rossiiskaia akademia nauk, Uralskoe otd-nie, Udmurtskii institut istorii, iazyka i literatury, pp. 126-170.

Wichmann, Yrjo 1893. Wotjakische sprachproben 1: Lieder, Gebete und Zauberspruche. Suomalaisen-ugrilaisen seuran Aikakauskirja, 11: 1. Helsingfors: Suomalaisen kirjallisuuden seuran kirjapaino.

Zelenin, Dmitri K. 1916. Ocherki russkoi mifologii [Main features of Russian mythology], 1. Peterburg.

\section{Manuscript sources}

AFM - author's fieldwork materials

VEM - collection of the Russian Ethnographic Museum 